\title{
Pengembangan Religious Culture Melalui Manajemen Pembiasaan Diri Berbasis Multikultural
}

\author{
Ardianto Tola, Abdul Muis Daeng Pawero, Nia Hariyati Tabiman \\ 1,2,3Institut Agama Islam Negeri Manado \\ e-mail: abdul.pawero@iain-manado.ac.id
}

\begin{abstract}
Religious Culture is an important religious culture that belongs to every human being, especially students. Because students are very vulnerable to the name of religious differences. Especially in a public school that has students with a variety of religions. This difference is sometimes a problem between religious groups. This study discusses the Development of Religious Culture in Junior High School 2 Tomohon. To further narrow the research, the researchers used the research process through Self-habituation Management conducted by the school. This study used a descriptive qualitative approach with locations in Junior High School 2 Tomohon. The research subjects were Religious Teachers, while the research Informants were Principals, Religion Teachers, and 7th and 9th Grade Students. The research method used was carried out through interviews, observation, and documentation. While the data validity technique uses triangulation methods and sources. The results of this study conclude that planning a religious culture development based on self-habituation management that comes from management functions namely Planning, Organizing, Actuating, Controling. Self-habituation management is to change the behavior of students who are carried out continuously so that they can be changed according to expectations. To implement Religious Culture at Junior Hugh School 2 Tomohon must have a definite goal so that its implementation runs effectively. The application carried out in schools is by small things such as greeting one another, no mockery of mockery, mutual respect, and mutual assistance. Thus, this application does not create a burden to students in Junior High School 2 Tomohon.
\end{abstract}

Keywords. Religious Culture; Management

Abstrak. Religious Culture merupakan budaya agama yang penting dimiliki setiap umat manusia, terutama para peserta didik. Karena peserta didik sangat rentan terhadap yang namanya perbedaan agama. Apalagi di suatu sekolah Negeri yang memiliki siswa dengan berbagai macam agama. Perbedaan ini yang kadang menjadi persoalan antar umat beragama. Penelitian ini membahas tentang Pengembangan Religious Culture yang ada di SMP Negeri 2 Tomohon. Untuk lebih mempersempit penelitian, maka peneliti menggunakan proses penelitian melalui Manajemen Pembiasaan Diri yang dilakukan oleh pihak sekolah. Riset ini menggunakan pendekatan kualitatif deskriptif dengan lokasi di SMP Negeri 2 Tomohon. Subjek penelitian adalah Guru Agama, sedangkan Informan penelitian adalah Guru Agama, Kepala Sekolah, Guru Agama, dan Siswa kelas 7 dan 9. Pengumpulan data dilakukan melalui wawancara, observasi, serta dokumentasi. Sedangkan tehnik keabsahan data menggunakan metode triangulasi. Teknik analisis data menggunakan model interaktif, yang diawali dengan pengumpulan data, reduksi data, penyajian data serta verifikasi. Penelitian ini menghasilkan temuan bahwa perencanaan pengembangan religious culture berdasarkan pada manajemen pembiasaan diri yang bersumber pada fungsi dari manajemen yaitu Perencanaan, Pengorganisasian, Penggerakkan, serta Pengawasan. Manajemen pembiasaan diri yaitu mengubah tingkah laku dari para siswa yang 
dilakukan secara berkala agar bisa diubah sesuai dengan harapan. Untuk menerapkan Religious Culture di SMP Negeri 2 Tomohon harus memiliki tujuan yang pasti agar penerapannya berjalan dengan efektif. Penerapan yang dilakukan di sekolah yaitu dengan hal kecil seperti saling sapa, tidak ada ejek mengejek, saling menghormati, dan saling membantu. Dengan demikian, penerapan ini tidak membuat beban kepada peserta didik di SMP Negeri 2 Tomohon.

Kata Kunci. Budaya Religius; Manajemen

Copyright (C) JMPI: Jurnal Manajemen Pendidikan Islam. All Right Reserved.

This is an open access article under the CC BY-NC-ND license

(http://creativecommons.org/licenses/by-nc-nd/4.0/).

\section{A. PENDAHULUAN}

Negara Indonesia merupakan salah satu Negara multi-etnis dan multi-agama terbesar di Dunia. Kebenaran pernyataan tersebut dapat diamati berdasarkan keadaan sosial maupun kultural serta kondisi geografis yang sangat beragam dan geografisnya yang sangat luas. Negara Indonesia sendiri memiliki 17.504 pulau. Sekitar sebelas ribu pulau ditempato oleh penduduk dengan 726 bahasa serta 359 suku. Mengacu pada Penetapan Presiden (PNPS) no.1 tahun 1969 yang telah dipertahankan di Mahkamah Konstitusi, Indonesia memiliki 6 agama resmi. Meski hanya 6, pada setiap agama tersebut terdapat berbagai aliran dalam wujud organisasi kemasyarakatan. Demikian pula dengan ratusan aliran kepercayaan yang telah ada sejak lama, yang hari ini masih berkembang di Indonesia (Muqoyyidin, 2013). Realitas negara Indonesia ini tentu membawa warna sekaligus tantangan tersendiri dalam dunia pendidikan.

Tantangan yang dimaksud yaitu perbedaan Agama, Suku, maupun Ras justru menyebabkan siswa berkumpul pada kelompok sendiri dalam belajar bahkan berpotensi menimbulkan perselisihan yang tajam antar siswa jika guru tidak mengawal keberagaman mereka. Sebagai upaya guru dalam menerapkan pembelajaran di tengah keberagaman siswa, maka implementasi pendidikan multikultural telah menjadi keniscayaan (Daeng Pawero, 2018). Hal tersebut karena pendidikan multi-kultur merupakan proses dalam tumbuh kembang sikap untuk saling hormat-menghormati antar sesama manusia, bersikap jujur, serta toleran terhadap kemajemukan budaya yang berangkat dari kesadaran akan adanya masyarakat yang beragam (Arifudin, 2017). Upaya meningkatkan pendidikan multikultur dapat menciptakan adanya kekuatan sosial serta kekuatan bangsa ini untuk menghadapi potensi benturan hingga konflik sosial.

Pada penelitian ini, penulis membahas beberapa point yang kemudian disatukan. Penulis membahas mengenai Pengembangan Religious Culture di sekolah melalui suatu Manajemen Pembiasaan diri yang berbasis Multikultural, yaitu seperti apa religious culture yang diterapkan di sekolah yang mana sekolah tersebut terdapat siswa dari berbagai macam ras, suku, budaya, dan lain sebagainya.

Religious Culture (Budaya Religi) adalah suatu model pendidikan moral serta nilai yang dapat diterapkan secara komprehensif. Ini dapat dilihat dalam perwujudannya yang terdapat pelajaran tentang nilai, keteladanan, serta pendidikan bagi generasi muda untuk dapat mempersiapkan diri agar mampu bersikap mandiri dengan memfasilitast serta mengajarkan pengambilan keputusan moral, dan mampu bertanggung jawab serta mampu menguasai keterampilan dan kecakapan hidup. Oleh 
karena itu, dalam upaya mewujudkan budaya religious di lembaga pendidikan, merupakan suatu upaya dalam menginternasilasikan norma-norma maupun nilai keagamaan ke dalam individu siswa (Putra, 2015).

Religious Culture dalam lingkungan sekolah merupakan suatu upaya untuk mewujudkan nilai-nilai ajaran agama sebagai kebiasaan dalam berperilaku dan serta upaya pembiasaan diri dalam organisasi yang diikuti oleh segenap personalia di dalam organisasi sekolah tersebut (Majid \& Andayani, 2011). Ketika segenap personalia menjadikan agama sebagai landasan nilai dan norma dalam organisasi sekolah, maka secara tidak lagsung, lembaga pendidikan tersebut telah bergerak menjalankan proses pendidikan menuju ketercapaian visinya dalam menjadikan siswa cerdas secara intelektual, maupun saleh secara spiritual (A. M. D. Pawero \& Dkk, 2019a). Oleh karena itu, Religious Culture atau budaya beragama di sekolah adalah suatu pola pikir maupun cara bertindak segenap personalia organisasi sekolah berdasarkan nilai-nilai Religious (keberagamaan). Dalam culture beragama di dalam organisasi sekolah, yang menjadi landasan utama adalah sekumpulan nilai-nilai serta norma-norma agama yang diterapkan di sekolah yang melandasi kebiasaan, perilaku, tradisi, bahkan pola hidup keseharian yang dipraktikan oleh seluruh warga dalam organisasi sekolah.

Pembiasaan norma maupun nilai agama (religi) di lingungan sekolah dapat memperkuat serta meningkatkan nilai persatuan, pengetahuan agama, dan kultus agama siswa di tengah keaneka ragaman suku, agama, ras dan sebagainnya (Banks, 2009). Karena itu, diperlukan langkah-langkah yang harus dilewati baik pada level nilai, praktik maupun simbol keagamaan. Maka dari itu dibutuhkan perilaku dan mentalitas dalam pembinaan melalui peradaban dalam kehidupan beragama di komunitas sekolah, keluarga, dan komunitas tempat siswa tinggal dan berinteraksi.

Pada Manajemen merupakan pencapaian visi organisasi berdasarkan kerja-kerja proesional melalui perencanaan dan pengelolaan serta kepemimpinan, dan pengendaian sumber daya-sumber daya organisasi. Pengertian ini memiliki dua pemikiran penting yaitu keempat fungsi perencanaan dan pengelolaan, kepemimpinan, serta pengendalian. Selain itu, juga upaya mencapai visi organisasi secara efektif, professional dan efisien (Daft, 2010).

Dilihat dari proses perkembangan, organisasi pendidikan sebagai suatu lembaga yang orientasinya tidak untuk tujuan-tujuan finansial, memaksa segenap personalia pendidikan mendayagunakan berbagai teori yang sebelumnya telah dikembangkan di dalam dunia ekonomi. Oleh karena itu, ketika meunculnya teori manajemen pendidikan, pada prinsipnya teori tersebut diadopsi dari teori manajemen yang sebelumnya dikembangkan dalam dunia non-profit (bisnis). Adopsi teori manajemen yang dikembangkan dalam dunia Pendidikan bukan berarti mengkomersialisasi lembaga pendidikan, akan tetapi semata-mata untuk digunakan sebagai landasan sistematis untuk mengelola organisasi/lembaga pendidikan. Selain itu, orientasi lembaga pendidikan berbeda dengan organisasi profit (bisnis). Jika organisasi bisnis bertujuan untuk mencari keuntungan ekonomi, lembaga pendidikan bertujuan untuk menjadikan manusia cerdas dan beradab. Maka dapat dilihat, orientasi ataupun tujuan yang diharapkan dalam mengelola lembaga pendidikan tentu berbeda dengan tujuan organisasi profit atau bisnis.

Jika dilihat dalam konteks organisasi pendidikan, pengelolaan (manajemen) dapat didefinisikan sebagai aktivitas yang memadukan sumberdaya-sumberdaya 
pendidikan dalam upaya mencapai tujuan pendidikan yang telah ditetapkan sebelumnya (Daeng Pawero, 2018). Diterapkannya prinsip manajemen sebagai landasan dalam melaksanakan program sekolah, agar segenap personalia serta pimpinan dalam lembaga pendidikan (sekolah) dapat berperan sebagai administrator maupun sebagai manajer dalam mengemban misi membina guru-guru pada proses belajar-mengajar (Subroto, 2010).

Upaya pimpinan lembaga pendidikan tersebut maka sebagai orang yang nantinya akan mengemban amanah untuk mengembangkan potensi peserta didik sebagaimana yang diharapkan berdasarkan tujuan pendidikan itu sendiri, setidaknya senantiasa memahami tentang teori manajemen yang dikembangkan dalam dunia pendidikan (A. M. D. Pawero \& Dkk, 2019b).

Pada penerapan pembiasaan diri, sangat diperlukan suatu perencanaan. Karena perencanaan yang dirumuskan dengan baik, maka akan mewujudkan hasil yang baik pula. Dalam perencanaan yang perlu diperhatikan adalah menetapkan beberapa hal terkait dengan apa saja yang mesti dilakukan, kapan waktunya serta bagaimana cara melakukannya, menetapkan tujuan sebaik mungkin serta menetapkan proses kerja dalam upaya untuk mencapai efektifitas kerja yang maksimal, memperhatikan dan menjalani proses penentuan target, mengembangkan rencana alternatif, dan mempersiapkan serta mengkomunikasikan rencana dan keputusan yang ditetapkan (Kristiawan, 2017).

Pembiasaan diri merupakan upaya menjalankan perilaku baik seperti pengembangan karakter dan religiusitas.

a. Karakter

Karakter adalah suatu nilai perilaku dasar manusia sebagai acuan tata nilai dalam interaksi antar manusia. Karakter secara universal dapat diartikan sebagai nilai atau norma kehidupan bersama berdasarkan pada pilar; saling menghargai, menjaga kedamaian, bekerjasama, persamaan derajat, kebahagiaan, kerendahan hati, kejujuran, kasih sayang, kesederhanaan, persatuan serta toleransi. Rangkaian sikap sebagai perwujudan karakter dapat dilihat dari perilaku, sikap, keterampilan serta motivasi. Individu yang berkarakter merupakan individu yang memiliki intelektual dan nilai moral yang ditandai dengan kemampuan berfikir kritis, perilaku jujur serta bertanggung jawab, berusaha untuk melakukan yang terbaik, mempertahankan integritas moral di tengah situasi penuh ketidakadilan, memiliki kecerdasan emosional dan interpersonal, serta komitmen untuk berkontribusi positif kepada masyarakat (Fitri, 2012). Selain itu, karakter juga dapat diartikan sebagai upaya realisasi perkembangan positif sebagai individu yakni aspek intelektual, sosial, etika, maupun emosional (Zubaiedi, 2011).

Berdasarkan penjelasan tersebut, dapat dipahami bahwa individu yang berkarakter atau memiliki karakter yang baik, merupakan orang yang dalam setiap aktiitasnya senantiasa berupaya melakukan yang terbaik. Dengan demikian, pendidikan karakter, berarti pendidikan yang mampu menstimulasi dan mengembangkan karakter peserta didik agar dapat menjadi generasi yang mampu berkontribusi dan memberi manfaat di tengah masyarakat. Sebagaimana inti dari karakter, pendidikan karakter berupaya untuk menjadikan peserta didik menjadi manusia yang religius, kreatif, produktif dan nasionalis. Dengan demikian,dapat dipahami bahwa pendidikan karakter merupakan segenap daya upaya guru dalam 
mempengaruhi peserta didik dengan menunjukkan keteladanan, tutur kata, toleransi, serta perilaku yang baik.

b. Religiusitas.

Religiusitas biasa diartikan oleh berbagai kalangan dengan istilah Agama. Menurut Frazer, Agama merupakan suatu sistem kepercayaan yang dri waktu ke watu selalu mengalami perkembangan sesuai dengan tingkat kognisi individu atau masyarakat penganut agama tersebut (Putra, 2015). Sedangkan Clifford Geertz, menjelaskan bahwa agama pada prinsipnya bukan hanya masalah spiritual, melainkan suatu hubungan intens antara agama sebagai sumber nilai, dengan agama sebagai sumber kognitif. Hal ini dapat dilihat pada pola di dalam agama yaitu sebagai pedoman yang mengarahkan manusia, serta merupakan pola tindakan manusia itu sendiri (A. M. Pawero, 2017).

Dengan demikian dapat dipahami bahwa religiusitas atau tindakan religius dapat terealisasi dalam berbagai dimensi kehidupan manusia. Perilaku beragama tidak hanya terjadi manakala seorang individu melakukan aktivitas ritual atau ibadah semata, melainkan ketika menjalani aktivitas lainnnya yang didorong berdasarkan kekuatan supranatural. Dengan kata lain, bukan sekedar yang berkaitan dengan yang kasat mata atau yang nampak, melainkan juga aktifitas yang tidak nampak, yang terjadi dalam hati sanubari seseorang.

\section{B. METODE}

\section{Jenis dan Pendekatan Penelitian.}

\section{a. Jenis Penelitian}

Jenis penelitian pada penelitian ini adalah penelitian atau riset lapangan (field research) yakni suatu riset yang dilaksanakan dalam rangka meneliti aktivitas hidup yang real atau kehidupan yang sebenarnya (Sugiyono, 2018). Riset lapangan bertujuan untuk mengkaji secara intens terkait dengan latar belakang keadaan saat ini, serta interaksi aktivitas sosial, kelompok, individu, lembaga, serta masyarakat (Usman, 2008).

b. Pendekatan Penelitian.

Sebagaimana dalam judul dalam penelitian ini, pendekatan yang dilakukan dalam penelitian ini menggunakan pendekatan Kualitatif Deskriptif. Di mana, riset tersebut bersifat deskriptif serta cenderung menggunakan analisis dengan metode induktif. Dalam pendekatan ini, perspektif atau sudut pandang informan lebih ditonjolkan.

Selain itu, alasan peneliti menggunakan Pendekatan Kualitatif Deskriptif adalah karena penelitian yang dilakukan ini berupaya mendeskripsikan, mengungkapkan dan menjelaskan secara intensif dan terperinci tentang judul yang diangkat yaitu "Pengembangan Religious Culture melalui Manajemen Pembiasaan diri yang berbasis Multikultural di SMP Negeri 2 Tomohon"

\section{Lokasi dan Waktu Penelitian.}

Tempat Penelitian ini dilakukan di SMP Negeri 2 Tomohon, Jln. Kasih Sayang, Kelurahan Kakaskasen, Kecamatan Tomohon Utara, Provinsi Sulawesi Utara. Adapun waktu penelitian dikerjakan selama lima bulan dimulai pada bulan Maret hingga bulan Agustus 2019. 


\section{Sumber Data.}

Dalam penelitian ini, informan ditentukan dengan menggunakan teknik purposes sampling yakni upaya pengambilan sumber data dengan pertimbangan-pertimbangan tertentu. Tujuan penggunaan teknik sampel yaitu mengambil beberapa responden serta informan yang dapat memberikan informasi terkait dengan permasalahan yang diangkat peneliti. Responden atau informan tersebut dipilih berdasarkan orang-orang yang memahami tentang point-point yang diteliti. Adapun informan dalam penelitian ini yaitu kepala Sekolah, Wakil kepala sekolah, Guru Agama serta sebagian siswa di SMP Negeri 2 Tomohon

\section{Metode Pengumpulan Data.}

Data yang relevan dengan permasalahan yang dihadapi tentu sangat diperlukan dalam setiap penelitian atau riset ilmiah. Hal ini karena kualitas data yang diperoleh ditentukan oleh kualitas pengumpulan data. Berikut ini merupakan metode pengumpulan data yang digunakan dalam riset ini.

a. Observasi

Metode Observasi merupakan suatu cara dalam upaya pengumpulan data, yaitu dengan cara mengamati secara langsung. Metode ini mencakup kegiatan-kegiatan pemusatan perhatian kepada objek penelitian dengan memanfaatkan seluruh panca indera. Metode ini dilakukan oleh penulis dalam penelitian dan mengamati gejalagejala atau kenyataan pada sasaran yang diteliti yang terkait dengan penelitian. Maka dalam teknik ini, penulis menggunakan teknik observasi dengan terjun langsung pada objek atau lokasi penelitian, yaitu di SMP Negeri 2 Tomohon.

b. Interview/Wawancara.

Metode wawancara atau interview merupakan suatu percakapan dengan maksud tertentu yang dilakukan oleh peneliti dengan informan. Dalam hal ini pewawancara mengajukan beberapa pertanyaan dan informan yang diwawancarai memberikan informasi atau jawaban atas pertanyaan-pertanyaan tersebut.

c. Dokumentasi.

Dokumentaasi adalah pengumpulan data berupa catatan peristiwa yang telah terjadi. Dalam hal ini, dokumen bisa berbentuk gambar-gambar, tulisan maupun karyakarya dari seseorang. Catatan harian, biografi, cerita, peraturan, kebijakan, sejarah kehidupan merupakan contoh dokumen berbentuk tulisan. Sedangkan sketsa, foto, dan sebagainya, merupakan beberapa contoh dokumen dalam bentuk gambar. Dalam penelitian kualitiatf, dokumentasi atau studi dokumen adalah pelengkap dari metode observasi dan wawancara (Sugiyono, 2018).

\section{Teknik Pengolahan dan Analisis Data.}

Tahap ini merupakan proses pencarian serta penyusunan secara sistematis berbagai data yang telah diperoleh dari hasil observasi, wawancara maupun dokumentasi dengan membuat pengelompokan data ke dalam kategori, melakukan sintesa, menyusun ke dalam pola, menjabarkan ke dalam unit-unit, serta memilih data yang paling penting yang akan dipelajari, serta membuat kesimpulan sehingga mudah dipahami oleh peneliti maupun orang lain.

Adapun komponen dalam analisis data terdiri dalam tiga tahapan yakni reduksi data, penyajian data, dan penarikan kesimpulan. 


\section{HASIL DAN PEMBAHASAN}

Suasana keagamaan yang ada di SMP Negeri 2 Tomohon pada umumnya sama dengan Sekolah Negeri lainnya yang ada di Tomohon. Setiap hari sekolah melaksanakan Ibadah Pagi sebelum KBM, memiliki toleransi yang cukup baik.

SMP Negeri 2 Tomohon memiliki ciri khas tersendiri dalam pelaksanaan yaitu pada bidang keagamaan yaitu khusus untuk agama Islam melakukan Tadzkir sebagai kegiatan ekstrakurikuler setiap hari Jum'at dilakukan setiap 2 minggu 1x. Selain itu, SMP Negeri 2 Tomohon adalah lembaga pendidikan yang mengoleksi banyak prestasi, baik dibidang akademik maupun2 non-akademik.

b. Penerepan dan pengembangan Religious Culture melalui Manajemen

Pembiasaan Diri.

1). Tahap Perencanaan.

Perencanaan yang dilakukan oleh pihak sekolah khususnya dari Kepala Sekolah adalah jelas dengan melihat permasalahan yang sesuai yang terjadi di SMP Negeri 2 Tomohon. Sebagaimana dikatakan

"Perencanaan yang saya susun berdasarkan dengan permasalahan yang terjadi. Setelah itu kita menentukan tujuan yang harus dicapai untuk pengembangan Religious Culture. Nah, dari hal itu akan menentukan langkah-langkah yang harus dilakukan. Apalagi ini berhubungan dengan Religious Culture yang sedikit sensitif karena berkaitan dengan Agama"

Penjelasan tersebut menunjukkan bahwa langkah pertama yang dilakukan untuk pengembangan Religious Culture yaitu dengan menentukan tujuan yang hendak dicapai. Tujuan tersebut yaitu dengan menyetarakan para peserta didik tanpa mendiskriminasi peserta didik yang lain.

Selain itu, melihat dari permasalahan yang ada di sekolah tersebut, banyak peserta didik yang mayoritas sering mendiskriminasi peserta didik yang minoritas di kelas mereka. Hal ini seperti diungkapkan oleh guru Agama Islam sebagai berikut:

"Peserta didik lebih cenderung hanya ingin berteman dengan teman-teman yang seagama. Apalagi yang kelas 7. Karena mereka masih sangat kurang pengetahuan apalagi berada dilingkungan yang berbeda agama. Mirisnya, cara mendiskriminasi mereka yaitu dengan mengejek. Hal tersebut sangat membuat resah para guru. Maka dari itu, para guru menyusun langkah-langkah perencanaan yang berbeda sesuai dengan permasalahan yang terjadi" sebagai berikut:

Hal tersebut juga seperti yang disampaikan oleh Guru Agama Kristen Protestan "Peserta didik yang baru sikapnya masih terbawa dengan sekolah mereka yang dulu, masih suka berkelompok-kelompok sesuai dengan sekolah mereka yang sebelumnya. Mereka tidak suka berbaur dengan teman-teman yang lain. Padahal mayoritasnya beragama Kristen tapi tetap saja mereka masih lebih suka berkelompok dengan tidak berbaur dengan teman-teman yang lain. Maka dari itu, kami para guru berusaha semaksimal mungkin untuk bisa mengubah para peserta didik dengan menggunakan langkah-langkah yang telah disiapkan"

Ternyata Manajemen Pembiasaan diri sangat berpengaruh penting dalam pelaksanaan pengembangan Religious Culture di SMP Negeri 2 Tomohon. Karena, dengan adanya manajemen pembiasaan diri, peserta didik mampu dengan mudah mengubah perilaku mereka di dalam lingkungan sekolah melalui kebiasaan setiap hari 
yang diterapkan oleh pihak sekolah.

Untuk langkah-langkah yang telah disesuaikan oleh Kepala Sekolah selaku pemimpin sekolah, ternyata para guru memiliki langkah-langkah perencanaan yang berbeda. Mereka menggunakan langkah-langkah yang sesuai dengan permasalahan yang terjadi disetiap para peserta didik. Penggunaan langkah-langkah perencanaan yang berbeda bertujuan agar bisa melihat sudah sejauh mana yang telah terlaksana berdasarkan perencanaan yang terjadi. Langkah yang seperti apa yang cepat terproses.

2). Tahap Penerapan.

Dalam perencanaan, pendekatan yang dilakukan untuk mempermudah jalan suatu proses, maka hal yang paling penting yaitu adanya penerapan. Penerapan dalam perencanaan merupakan puncak atau akhir dari proses perencanaan sebelumnya. Maka dari itu, dalam menerapkan perencanaan harus tepat serta sesuai sebagaimana yang telah ditetapkan berdasarkan kebijakan yang ada dan metode serta langkah-langkah pelaksanaan yang telah disiapkan sebelumnya.

Ada berbagai macam pelaksanaan yang dilakukan pihak sekolah khususnya Kepala Sekolah yang merupakan Leader di Lembaga Pendidikan tersebut. Salah satu pelaksanaan yang dilakukan pada awal mula masuk sekolah yaitu adanya Masa Orientasi Siswa yang pada hari terakhir guru tiap agama mengajak peserta didik sesuai dengan agama mereka lalu saling mendekatkan diri.

Uraian tersebut sebagaimana disampaikan oleh Kepala Sekolah dalam wawancara bahwa :

“Pelaksanaan perencanaan sangat penting karena dari sini kita akan melihat sampai mana tingkat kesuksesan perencanaan yang telah disusun oleh pihak sekolah. Pelaksanaan yang sering dan setiap tahun dilakukan oleh pihak sekolah yaitu mengadakan MOS pada awal masuk sekolah. Pada umumnya, MOS disemua sekolah sama hanya saja di SMP Negeri 2 Tomohon menggunakan teknik yang berbeda. Yaitu ada 1 hari terakhir dimana semua siswa kelas 7 dikumpulkan berdasarkan dengan Agama yan dianut oleh mereka. Dan disitu guru yang memiliki agama yang sama dengan peserta didik itu yang menuntun mereka selama 1 hari itu. Para guru akan melakukan pendekatan emosional dengan melihat karakter setiap peserta didik itu seperti apa, dan dari situ guru akan melaksanakan tugas mereka sesuai dengan langkah apa yang telah mereka susun sebelumnya"

Proses pelaksanaan pengembangan Religious Culture yaitu dengan adanya pembiasaan diri. Pembiasaan diri merupakan hal yang penting dalam pengembangan Religious Culture. Karena apabila tidak ada pembiasaan diri, maka interaksi antar siswa dengan latar belakang berbeda antara satu dengan yang lain tidak akan maksimal. Hal tersebut tentu berdampak pada output peserta didik tidak akan baik.

Pembiasaan diri yaitu bagaimana seseorang mampu melakukan suatu hal secara terus menerus tanpa ada paksaan lagi. Memang, awal mula terciptanya pembiasaan diri yatu dengan dipaksa. Sama halnya di Pesantren atau di Asrama, banyak peserta didik yang tidak terbiasa bangun pagi dan ibadah, namun ketika berada ditempat itu mereka harus dipaksa untuk melakukan hal yang mereka tidak biasa lakukan. Pelaksanaan pembiasaan diri yang dilakukan kepada peserta didik dari para guru berbeda-berda setiap agama. Namun, pada dasarnya pihak sekolah selalu menekankan pada pseserta didik tentang adab. Karena dari adab itulah para siswa dapat lebih 
mudah melakukan Pembiasaan diri.

Hal tersebut seperti telah diungkapkan oleh Guru agama Islam dalam wawancara, bahwa:

“Kami para guru memiliki metode yang berbeda dalam pelaksanaan proses pengembangan Religious Culture. Namun, kami semua selalu mengutamakan adab dalam pelaksanaan proses tersebut. Karena pembiasaan melalui adab yang sangat sulit diterapkan kepada peserta didik. Maka dari awal masuk sekolah kami selalu membiasakan peserta didik dengan memberi salam kepada guru dan teman-teman entah dia sama agama ataupun berbeda"

Selain itu, penguatan dari penerapan Religious Culture yaitu di setiap pagi dilaksanakan Ibadah pagi dan dipisahkan para peserta didik berdasarkan agama yang dianut. Hal tersebut tujuannya agarpara siswa mrmahami pelaksanaan keagamaan mereka dengan baik dan kemudian akan menjadi kebiasaan bagi mereka. Sebagaimana penjelasan guru agama kristen katolik sebagai berikut;

“Setiap pagi kami melakukan ibadah pagi. Kegiatan ini sudah menjadi kegiatan yang rutin dilakukan pihak sekolah setiap pagi sebelum mulai KBM (Kegiatan Belajar Mengajar). Kemudian, kami pisahkan siswa muslim, dengan siswa yang kristen protestan dan katolik. Hal ini bertujuan agar para peserta didik lebih menguatkan diri mereka terhadap keagamaan yang mereka anut, dan mereka paham betul seperti apa agama mereka"

Penjelasan tersebut juga senada dengan yang disampaikan oleh Guru Agama Kristen Protestan dalam wawancara, bahwa;

"Di sekolah ini ada yang namanya Ibadah pagi. Ibadah pag bertujuan untuk penguatan iman terhadap peserta didik juga pihak sekolah. Apalagi dilakukan setiap pagi sebelum KBM maka akan menambah ketekunan kita terhadap Tuhan. Kami membedakan antara Islam dengan Kristen dalam ibadah karena proses ibadah kami berbeda

Kegiatan ekstrakurikuler juga penting dilakukan untuk pengembangan Religious Culture. Salah satu contoh kegiatan ekstrakurikuler yaitu adanya Tadzkir tiap minggunya. Sebagaimana dijelaskan guru agama Islam sebagai berikut:

“Di SMP Negeri 2 Tomohon diterapkan kegiatan ekstrakurikuler. Kegiatan ini bertujuan untuk menambah wawasan dan melihat kemampuan peserta didik di luar bidang akademik. Namun, saya membuat program untuk peserta didik yang beragama Islam untuk melakukan Tadzkir setiap 2 minggu 1x. Hal ini dikarenakan kekurangan peserta didik yang beragama Islam yang masuk di SMP Negeri 2 Tomohon. Dan agar mereka senang menghadiri Tadzkir maka saya bekerja sama dengan sekolah-sekolah lain seperti MTs Al-Mujahidin untuk melakukan Tadzkir".

Berdasarkan uraian tersebut, maka dapat disimpulkan bahwa penerapan dalam pengembangan Religious Cultrue di SMP Negeri 2 Tomohon berdasarkan pada Manajemen Pembiasaan diri yang bertujuan untuk mengubah perilaku peserta didik lebih baik dengan mengajarkan secara terus menerus. Kemudian, untuk mempermudah dalam penerapan pihak sekolah menggunakan pendekatan perencanaan yang nantinya penerapannya dapat dilakukan secara bertahap dan terstruktur.

c. Problematika Penerapan Religios Culture.

Religious Culture sangat sensitif jika langsung dikaitkan dengan peserta didik. 
Banyak sekali problematika yang terjadi ketika penerapan pengembangan Religious Culture di SMP Negeri 2 Tomohon. Salah satu problematika yang terjadi yaitu dari keluarga. Sebagaimana disampaikan guru agama Katolik sebagai berikut:

"Kami pihak sekolah sangat ingin adanya toleransi di sekolah ini. Agar benar terjadi apa yang di katakan Walikota bahwa Tomohon memiliki tingkat toleransi yang besar. Namun, tidak semua orangtua paham dengan anak mereka. Tidak semua orangtua paham dengan Religious Culture. Masih banyak orangtua yang awam tentang hal tersebut. Mereka kurang ada kepedulian terhadap anak mereka. Pada awal masuk sekolah, bahkan banyak anak-anak yang tidak suka bergaul dengan teman baru, karena ada sebagian orangtua yang memberi mindset untuk tidak bergaul dengan teman-teman yang beragama lain. Hal ini membuat kami para guru sedikit cemas dengan mindset dari pihak orangtua"

Problematika yang terjadi sering membuat para guru kesulitan untuk menerapkan religious culture. Seperti problematika lain yang sering terjadi di sekolah yaitu kurangnya nilai agama dari para peserta didik di SMP Negeri 2 Tomohon. Ternyata, hal ini sudah tertanam dalam ranah keluarga. Orangtua yang kurang peduli dengan mereka membuat peserta didik menjadi tidak baik dalam nilai agama. Hal tersebut seperti dituturkan Guru Agama Kristen Protestan sebagai berikut:

"Banyak peserta didik yang tidak ingin di didik. Mereka sering menganggap bahwa didikkan hanya main-main. Contoh kecil yaitu memberi salam kepada guru, tapi mereka tidak melakukan itu. Mereka hanya menganggap itu sebagai candaan. Setelah ditelusuri dari pihak sekolah, ternyata di rumah mereka tidak diajarkan nilai agama dan sopan santun. Mereka sering dibiarkan di rumah karena orangtua mereka hanya sibuk dengan urusan mereka tanpa memerhatikan anak-anak mereka."

Dari beberapa uraian di atas dapat, diketahui bahwa pihak sekolah sangat bekerja keras untuk proses pengembangan Religious Culture di SMP Negeri 2 Tomohon. Walaupun memiliki banyak kendala namun mereka ingin terus membuktikan bahwa sekolah di Tomohon memiliki toleransi beragama yang besar

d. Dampak penerapan Religious Culture.

Setiap penerapan suatu kegiatan pasti mengharapkan hasil yang baik yang sesuai dengan tujuan yang telah disusun bersama. Sejauh mana keberhasilan dari penerapan Religious Culture di SMP Negeri 2 Tomohon. Ada beberapa dampak yan terjadi pada peserta didik dan pihak sekolah setelah penerapan pengembangan Religious Culture di SMP Negeri 2 Tomohon. Dampak yang umum itu terjadi pada siswa yaitu perubahan perilaku para siswa. Sebagaimana disampaikan oleh salahsatu siswa kelas 9 bahwa;

“Dulu, waktu saya masih kelas 7 saya kurang paham mengenai Reiligious Culture seperti apa. Saya tidak paham tentang adanya perbedaan agama. Tapi, setelah saya belajar saya mendapatkan banyak pengetahuan dan saya sudah terbiasa memberi salam kepada semua orang yang berpapasan dengan saya. Selain itu, saya juga sudah sering sholat di Masjid walaupun belum 5 waktu."

Hal tersebut sebagaimana juga telah disampaikan oleh salahsatu siswa kelas 9 dalam wawancara, bahwa:

"Saya tahu bahwa Religious Culture yaitu budaya beragama. Di mana banyak perbedaan agama yang ada di Tomohon ini. Namun, saya dapatkan perbedaan itu 
ketika saya sekolah di SMP Negeri 2 Tomohon. Para guru juga sangat intens melaksanakan tugas mereka agar kami para siswa bisa beradaptasi dengan baik dan cepat tentang Religious Culture. Saya sudah terbiasa memberi salam kepada guru, orangtua, maupun orang-orang yang ada di jalan yang saya temui"

Dari hasil temuan penelitian di atas, dapat simpulkan bahwa impact yang terjadi ketika menerapkan Religious Culture di SMP Negeri 2 Tomohon sangat berpengaruh. Karena, perubahan sikap serta perilaku para siswa membuat para guru merasa penerapan ini berhasil. Dengan adanya Pembiasaan Diri membuat peserta didik melakukan tindakan secara terus menerus dan continue. Hal ini bisa membuktikan bahwa SMP Negeri 2 Tomohon memiliki nilai keagamaan yang cukup baik.

\section{Pembahasan.}

a. Penerapan Pengembangan Religious Culture Melalui Pembiasaan Diri

Dalam setiap organisasi baik organisasi pendidikan, organisasai masyarakat mauupun organisasi lainnya, dalam penerapan suatu kegiatan yang hendak dilakukan pasti memerlukan perencanaan. Perencanaan itu sendiri adalah salah satu fungsi manajemen yang paling awal sebelum fungsi manajemen lainnya. Perencanaan yang memiliki tingkat kematangan yang tinggi sangat dibutuhkan dalam menjalankan kegiatan organisasi. Kegiatan dalam organisasi sekolah tidak akan berjalan dengan lancer jika tidak adanya perencanaan yang matang sebelumnya. Demikian pula sebelum penerapan Religious Culture di SMP Negeri 2 Tomohon, terlebih dahulu melakukan perencanaan berkaitan dengan kegiatan-kegiatan yang akan dilaksanakan.

Penerapan religious culture di SMP Negeri 2 Tomohon mempunyai landasan dan dasar yang kuat, baik secara konstitusional, maupun secara normatif. Sehingga sekolah dituntut untuk terus bergerak mengupayakan kegiatan tersebut yakni upaya mewujudkan penerapan religious culture pada para siswa di SMP Negeri 2 Tomohon. Dengan upaya menumbuh kembangkan nilai serta norma agama melalui pembiasaan pada diri paad siswa di SMP Negeri 2 Tomohon maka akan memperkokoh iman maupun aplikasi nilai-nilai religi tersebut, serta dapat menciptakan budaya religi dilingkungan sekolahnya. Dengan menerapkan upaya pembiasaan diri untuk menerapkan budaya religi seperti ibadah pagi bagi kriseten dan zikir pagi bgi muslim yang senantiasa diterapkan oleh para guru kepada peserta didik kepada peserta didik, maka akan mempengaruhi sifat maupun tindakan-tindakan para siswa. Selain itu, pihak sekolah selalu menekankan pada peeserta didik tentang pentingnya mengedepankan adab. Karena dari adab itulah peserta didik akan lebih mudah melakukan pembiasaan diri dalam penerapan religious culture. Penerapan religious culture bagi peserta didik di SMP Negeri 2 Tomohon sebagaimana dalam temuan penelitian, dapat berpengaruh pada pengembangan sikap, sifat maupun tindakan para siswa baik langsung maupun tidak langsung.

b. Problematika Penerapan Religious Culture.

Setiap kegiatan yang diterapkan dalam dunia pendidikan, organisasi, dan pada masyarakat luar pasti memiliki problematika yang terjadi pada proses penerapan kegiatan tersebut. Hal tersebut juga terjadi dalam upaya penerapan religious culture di SMP Negeri 2 Tomohon, di mana masih terdapat beberapa problematika yang terjadi saat penerapan pengembangan Religious Culture di SMP Negeri 2 Tomohon.

Problematika dalam hal ini yaitu berbagai macam persoalan rumit yang dihadapi selama proses penerapan religius culture melalui pembiasaan diri, baik yang 
datang dari faktor internal (Guru dan peserta didik) maupun dari faktor eksternal (Orangtua, dan masyarakat yang terkait).

SMP Negeri 2 Tomohon terkenal dengan sekolah yang di dalamnya terdapat peserta didik yang sebagian besar memiliki orangtua yang kurang peduli terhadap anak mereka. Hal ini yang menjadi problematika utama dari penerapan Religious Culture di sekolah tersebut. Adanya ketidakpedulian dari pihak orangtua membuat anak malas untuk beradaptasi di sekolah. Kurangnya kepedulian orang tua tersebut jelas terlihat pada sikap beberapa peserta didik yang mengnggap kegiatan-kegiatan keagamaan seperti ibadah pagi sebagai candaan semata. Hal ini jelas membuat proses penerapan religious culture menjadi terganggu. Selain itu, proses belajar mengajar juga jelas akan terganggu. Karena dari penerapan ini mengharapkan aktivitas pembelajaran dapat berjalan dengan efektif dan efisien berdasarkan tujuan yang telah disusun bersama.

c. Dampak Penerapan Religious Culture.

Impact (dampak) dapat diartikan sebagai akibat, pengaruh, maupun imbas yang terjadi, baik itu dampak baik atau buruk, dari suatu tindakan yang telah diperbuat oleh individu atau kelompok yang melakukan aktivitas atau kegiatan tertentu.

Kata "dampak" itu sendiri telah lazim digunakan oleh masyarakat dalam kehidupan sehari-hari, bahkan familier di semua kalangan dengan berbagai usia. Biasannya, penggunakan kata "dampak" dibarengi dengan kata "imbas" sebagai akhir dari pelaksanaan suatu kegiatan yang dilakukan, baik positif maupun negatif.

Berdasarkan hasil penelitian, peneliti dapat menyimpulkan bahwa terdapat dampak yang positif terkait dengan penerapan Religious Culture melalui pembiasaan diri di SMP Negeri 2 Tomohon. Dampak positif ini dirasakan oleh sejumlah siswa yang mengikuti penerapan Religious Culture yang dilakukan oleh pihak sekolah SMP Negeri 2 Tomohon. Banyak perubahan yang dirasakan sejumlah siswa di sekolah itu. Dampak positif itu yang kemudian dapat mempermudah peserta didik untuk menghadapi kehidupan dunia yang lebih luas lagi. Lebih mudah menghadapi problematika yang lebih besar yang berkaitan dengan Religious Culture karena mereka sudah memiliki bekal pengetahuan dan adaptasi yang bagus di SMP Negeri 2 Tomohon.

\section{KESIMPULAN}

Berdasarkan hasil penemuan penelitian di SMP Negeri 2 Tomohon, kesimpulan dalam penelitian ini dapat diuraikan sebagai berikut;

1. Upaya penerapan Religious Culture melalui Manajemen Pembiasaan Diri sangat penting diberikan kepada peserta didik khususnya di SMP Negeri 2 Tomohon karena di SMP masa yang baik untuk anak berkembang. Karena Religious Culture juga penting diberikan kepada peserta didik sebagai bekal ketika menghadapi lingkungan luar.

2. Problematika yang dihadapi lebih condong berasal dari orangtua. Maka dari itu pendidik melakukan Manajemen atau Perencanaan agar kendala yang hendak dihadapi sudah bisa diketahui dan bisa menyediakan solusi lebih awal dari sebelumnya.

Impact yang terjadi dari penerapan Religious Culture bagi peserta didik yaitu bisa menerapkan apa yang telah diberikan dan bisa membuktikan kepada masyarakat luar kalau di SMP Negeri 2 Tomohon bisa menerapkan Religious Culture dengan baik. 


\section{REFERENSI}

Arifudin, I. (2017). Urgensi Implementasi Pendidikan Multikultural di Sekolah. Jurnal Pemikiran Alternatif Pendidikan, 2.

Banks, J. A. (2009). Multicultural Education: Carakteristic and Goals. Boston: Allyn and Baccon.

Daeng Pawero, A. M. V. (2018). Analisis Kritis Kebijakan Kurikulum Antara KBK, KTSP, dan K-13. Jurnal Ilmiah Iqra', $12(1), \quad 42$. https:/ / doi.org/10.30984/jii.v12i1.889

Daft, R. L. (2010). Era Baru Manajemen. Jakarta: Salemba Empat.

Fitri, A. Z. (2012). Pendidikan Karakter Berbasis Nilai dan Etika di Sekolah. Yokyakarta: ArRuzz Media.

Kristiawan, M. (2017). Manajemen Pendidikan. Yogyakarta: Budi Utama.

Majid, A., \& Andayani, D. (2011). Pendidikan Karakter dalam Prespektif Islam. Bandung: Remaja Rosdakarya.

Muqoyyidin, A. W. (2013). Membangun Kesadaran Inklusif-Multikultural untuk Deradikalisasi Pendidikan Islam. Jurnal Pendidikan Islam, Volume II(1), 132.

Pawero, A. M. (2017). Analisis Kritis Kebijakan Standar Kompetensi Lulusan (SKL) Dan Standar Isi Kurikulum Pendidikan Agama Islam. Journal of Islamic Education Policy, 2(2). https://doi.org/10.30984/j.v2i2.700

Pawero, A. M. D., \& Dkk. (2019a). Contemporary Issues on Religion and Multiculturalism. Manado: Cv. Istana Agency.

Pawero, A. M. D., \& Dkk. (2019b). The Scientific Paradigm of Islamic Education Management. In Procceding The 2nd Annual Conference on Islamic Education Management (Vol. 53, pp. 1689-1699). https://doi.org/10.1017/CBO9781107415324.004

Putra, K. S. (2015). Implemetasi PAI melalui Budaya Religious di Sekolah. Jurnal Kependidikan, 3(2), 25.

Subroto, S. (2010). Manajemen Pendidikan di Sekolah (2nd ed.). Jakarta: Rineka Cipta.

Sugiyono. (2018). Metode Penelitian Pendidikan (Kuantitatif, Kualitatif, Kombinasi, RED dan Penelitian Pendidikan). Bandung: Alfabeta.

Usman, H. (2008). Manajemen, Teori Praktik dan Riset Pendidikan. Jakarta: Bumi Aksara.

Zubaiedi. (2011). Desain Pendidikan Karakter; Konsepsi dan Aplikasinya Dalam Lembaga Pendidikan. Jakarta: Kharisma Putera Utama. 